\title{
Life history and demography of three populations of Ophryotrocha japonica (Polychaeta: Dorvilleidae)
}

\author{
R. Simonini*, D. Prevedelli \\ Dipartimento di Biologia Animale, Università di Modena e Reggio Emilia, Via Campi 213D, 41100 Modena, Italy
}

\begin{abstract}
This paper examines the life history and demography of 3 populations of the polychaete Ophryotrocha japonica, an alien species that until 2001 had only been reported in harbour environments along the Asian and American coasts of the Pacific. The populations analysed came from the Italian harbours of Leghorn and Ravenna, and from the brackish Mar Piccolo of Taranto. The 3 strains are inter-fertile, both with one another and with their Pacific counterparts, but were nevertheless found to have morphological, reproductive and demographic differences. In the Leghorn and Taranto populations there is a sort of sexual dimorphism based on body size that is not present in the Ravenna strain, while the most important differences concern their reproductive characteristics, with great variations being observed in their respective fecundity, egg size and reproductive investment. The differences in life history have very important consequences for the demography and fitness of each population. In particular, morphometric, reproductive and demographic characteristics set the Leghorn population apart from the other 2; it reaches sexual maturity more rapidly, lives longer, is decidedly larger and its population growth rate $\lambda$ is $2.26 \mathrm{wk}^{-1}$. The Ravenna and Taranto populations appear to be more alike; their eggs are the same size, they are equally fecund, make a similar reproductive investment and have $\lambda$-values of 1.82 and $1.83 \mathrm{wk}^{-1}$, respectively. The marked differences observed among the 3 populations may depend on the species' adaptation to different environmental situations, but could also be the result of independent introductions from different localities or at different times.
\end{abstract}

KEY WORDS: Life history $\cdot$ Demography $\cdot$ Population $\cdot$ Ophryotrocha japonica $\cdot$ Polychaeta

Resale or republication not permitted without written consent of the publisher

\section{INTRODUCTION}

The most important traits of marine invertebrate life histories are connected essentially with reproduction and survival. Timing of development and maturation, number and size of offspring and age- or stage-specific survival are just some of the aspects of the individual's life history. Such characteristics are often closely related, and are the result of interactions between phylogenetic, physiological and morphological constraints, and the processes by which the organisms adapt to the environment in which they live and reproduce (Giangrande 1997, Brommer 2000). Local adaptation could promote the differentiation of geographically separated populations that may differ not only in genetic and morphological characteristics, but also in some life-history traits (Grassle \&
Grassle 1974, 1976, Cognetti 1982, 1994, Méndez et al. 2000).

Organisms have evolved a number of ways of combining life-history characteristics in order to enhance fitness. The indices most commonly used to express fitness are the population growth rate $\lambda$ (or the intrinsic growth rate $r=1 \mathrm{n} \lambda$ ) and the net reproductive rate $R_{0}$. Both indices provide an estimate of population growth and can be used as indices of fitness, in that, by integrating the different contributions of fecundity and age-specific survival, they offer synthetic information that is not available through analysis of an individual's single parameters. Moreover, $\lambda$ is considered a better index of fitness than $R_{0}$ i the most recent demographic models applied to the study of life histories in fact use population growth rate $\lambda$ as the main indicator of fitness (Stearns 1992, Brommer 2000, Caswell 2000, Huey \& 
Barrigan 2001, Prevedelli \& Simonini 2001a,b). A method for evaluating the consequences of environmental or biological factors for individual life-history parameters at population level, combining approaches that have traditionally been followed separately, is life-table response experiments (Caswell 2000). This method has been used to test the effects of environmental parameters, intra-specific density, larval development mode, different genetic strains, seasonality, laboratory rearing and exposure to pollutants in polychaete species such as Streblospio benedicti, Capitella sp, Ophryotrocha diadema and, more recently, Ophrytrocha labronica and Dinophilus gyrociliatus (Åkesson 1976, Levin et al. 1987, 1996, Hansen et al. 1999, Prevedelli \& Simonini 2001a,b, 2002, Mauri et al. 2002).

Ophryotrocha japonica nomen nudum (Pleijel \& Eide 1996) is a gonochoric semi-continuous iteroparous polychaete belonging to the Dorvilleidae family colonising harbour and brackish environments. $O$. japonica has only recently been reported along the Italian coasts, but it is widely distributed and abundant (Simonini 2002). It is an alien species, for until 2001 it had only been reported in harbour environments along the Asian and American coasts of the Pacific Ocean (B. Åkesson pers. comm.). No studies regarding the morphology, life-cycle and -history of O. japonica have hitherto been published. In this study we investigate the life-history characteristics of 3 populations of O. japonica, with the aim of evaluating the existence of differences in the life-history traits of the 3 strains, and of performing a demographic analysis to link individual to population parameters.

\section{MATERIALS AND METHODS}

Ophryotrocha japonica. O. japonica is similar to $O$. labronica, a typical Mediterranean species, but differs from it on account of certain characteristics, such as maximum size, head shape and pigmentation, and some reproductive traits. Like that of O. labronica, the head of $O$. japonica displays 2 short antennae and no palps, and the right branch of the forceps has a double apical tooth. The diploid chromosome number is $2 \mathrm{n}=$ 6 chromosomes. O. japonica also has some distinctive features: the adults are frequently more than $5 \mathrm{~mm}$ in length and have a roundish, enlarged head lacking the transverse strand of pigments between the 2 eyes that characterises O. labronica. O. japonica lays eggs in rigid, tubular or 'spoon-shaped' masses: males fertilise the eggs by pseudo-copulation just after spawning. Both males and females share parental care of the developing embryos. The larvae of $O$. japonica hatch from the egg clusters with 2 to 3 setigers; the larvae of other species of Ophryotrocha living along Italian coast hatch without setigers (Simonini 2002). Our specimens were identified as O. japonica on the basis of their morphological characteristics and of karyological investigations performed with Giemsa staining on developing embryos (according with the technique outlined by Jha et al. 1995), and also by crossing them with standard strains previously classified by Prof. Bertil Åkesson of the University of Göteborg, who maintains 'the Ophryotrocha gene bank' (cultures of 18 species of Ophryotrocha) in his laboratory. The populations used in this study are inter-fertile, both with one another and with their Pacific counterparts.

Collection and maintenance. The populations analysed were collected from the Italian harbours of Leghorn and Ravenna and from the brackish Mar Piccolo of Taranto in November 2000. Samples of fouling material (consisting mainly of mussels, ascidians, bryozoan and serpulid polychaetes) were taken by scraping the wharves and other hard substrates. In all the localities Ophryotrocha japonica was found together with $O$. labronica, each locality yielding more than 60 worms. After collection, the animals were housed in $10 \mathrm{~cm}$ diameter beakers containing ca. $200 \mathrm{ml}$ of artificial $32 \mathrm{psu}$ seawater, and maintained at $24^{\circ} \mathrm{C}$ with a $12: 12 \mathrm{~h}$ light:dark photoperiod. Twice a week, the animals were fed with abundant quantities of frozen spinach. The descendants of these specimens were used to build up 3 laboratory-reared groups, one for each population being studied, in order to exclude any maternal effects from the experiments. More details regarding worm collection and laboratory rearing are reported in Prevedelli \& Zunarelli Vandini (1998) and Simonini (2002).

Description of the experiments. The experiments started in February 2001. Approximately 30 newly-laid egg masses from each population were isolated, together with the parents, in new beakers and checked daily. As soon as the larvae began to hatch, the parents were removed, thus ensuring that a large number of individuals of the same age and known date of birth were selected. The age at maturity was assessed as the period of intratubular development of embryos before larvae were released. The juveniles were checked every $2 \mathrm{~d}$. Twenty days after birth, the individuals reach a length of ca. 13 setigerous segments. At this size there is an apparent dimorphism between males and females in the jaw, and the developing oocytes are visible through the body wall of the females; thus, it is possible to distinguish the males from the females, determine the sex ratio (\% of males, estimated from each initial brood) and proceed to couple them. As in Ophryotrocha labronica, in O. japonica there is an apparent dimorphism between males and females in the jaw, and the developing oocytes are visible through the body wall of the females.

More than 30 pairs were established for each of the 3 populations of Ophryotrocha japonica. Each pair was 
isolated in a Boveri dish (diameter $4.5 \mathrm{~cm}$, height $2.5 \mathrm{~cm}$ ) containing ca. $15 \mathrm{ml}$ of 32 psu artificially prepared sea water. The experiment was conducted at $24^{\circ} \mathrm{C}$ and with a $12: 12 \mathrm{~h}$ light:dark photoperiod. The laboratory food consisted of frozen spinach.

The pairs were checked twice a week to see whether reproduction had occurred. If so, the fecundity and growth rate were recorded. If the male died, it was replaced; if the female died, the pair was eliminated from the experiment. The age and size of the female at maturity was measured when it laid its first egg mass. The fecundity of each pair was assessed as the number of eggs produced at each spawning by the female, the number of spawnings, and the total number of eggs produced by a female during her lifetime. Once counted, the eggs were eliminated. The size of the eggs was determined by measuring at least 30 recently spawned eggs of a number of females for each population (at least 1 egg for each female). The evening before, the pairs were checked to make sure that the eggs being measured (developing embryos) had been laid during the night. The eggs of Ophryotrocha japonica are not perfectly spherical, so both the longer and the shorter axes were measured, and the egg volume $(V)$ was calculated as:

$$
V=\frac{4}{3} \pi A^{2} B
$$

where $A$ is the short radius and $B$ the long radius, according to Qian \& Chia (1991) and Prevedelli \& Zunarelli Vandini (1998).

For simplicity, egg size was calculated as the arithmetic mean between the longer and the shorter axes. Growth rate was recorded by counting the number of setigerous segments: the size of the adult was assessed by referring to the maximum size that the female and initial male of each pair reached during their lives. The males used to replace the initial ones when they died were not considered. The experiment continued until all females had died.

Data analysis. The differences in life-history characteristics of the 3 populations were assessed by ANOVA. When ANOVA was significant, an a posteriori LSD test was performed. The reproductive investment was obtained by multiplying individual fecundity by the egg volume. Age-specific survivorship and fecundity schedules of females were obtained for each population examined. These life-table data were used to build a complete age-classified population model and the relative projection matrices (Leslie matrices), using a projection interval of $1 \mathrm{wk}$. Since this species exhibits a semi-continuous reproductive mode, the survival probabilities $\left(P_{i}\right)$ appearing on the subdiagonal were calculated as:

$$
P_{i}=\frac{l_{(i+1)}+l_{(i)}}{l_{(i)}+l_{(i-1)}}
$$

and the age-specific fecundity $\left(F_{i}\right)$ in the first row as:

$$
F_{i}=\left(l_{(0)} l_{(1)}\right)^{1 / 2} \frac{\left(m_{1}+P_{i} m_{i+1}\right)}{2}
$$

where $l_{(i)}$ is survivorship from zygote to age $i$ and $m_{i}$ is the average number of female offspring per female in age class $i$ (Caswell 2000).

The finite population growth rate $\lambda$ was calculated as the dominant eigenvalue of each matrix. The stable age distribution is given by the corresponding right eigenvector (w) and the reproductive value distribution by the corresponding left eigenvector $(\mathbf{v})$. The sensitivities of $\lambda$ to changes in the matrix entries $P_{i}$ and $F_{i}$ $\left(S_{P_{i}}\right.$ and $S_{F_{i}}$ respectively) were calculated according to Caswell (2000):

$$
\begin{aligned}
& s_{P_{i}}=\frac{\partial \lambda}{\partial P_{i}}=\frac{\mathbf{w}_{i} \mathbf{v}_{1}}{\langle\mathbf{w}, \mathbf{v}\rangle} \\
& s_{F_{i}}=\frac{\partial \lambda}{\partial F_{i}}=\frac{\mathbf{w}_{i} \mathbf{v}_{i+1}}{\langle\mathbf{w}, \mathbf{v}\rangle}
\end{aligned}
$$

where $\langle\mathbf{w}, \mathbf{v}\rangle$ denotes the scalar product between the stable age composition and the reproductive value.

Sensitivity is determined by the life history of the organism as described by $P_{i}$ and $F_{i}$. However, since survivorship and fecundity are measured on different scales, the absolute values of the sensitivities of different parameters cannot readily be compared. To overcome this difficulty, the measure of relative sensitivity, known as elasticity $\left(e_{a}\right)$, was calculated:

$$
e_{a}=\frac{a}{\lambda} s_{a}
$$

where $a$ denotes the life-history trait $P_{i}$ or $F_{i}$ under consideration (Levin et al. 1987, Caswell 2000).

The difference in $\lambda$ of each population was decomposed into contributions from each of the agespecific survivorship and fecundity terms using the techniques outlined by Caswell (2000). Let $\lambda^{(c)}$ and $\lambda^{(d)}$ denote the values of $\lambda$ for Populations $c$ and $d$, respectively. Then:

$$
\Delta \lambda=\lambda^{(c)}-\lambda^{(d)}=\sum_{i} \sum_{j} \Delta a_{i j} \frac{\partial \lambda}{\partial a_{i j}}
$$

Each term in the summation is the contribution of the difference in the matrix entry $a_{i j}$ of Population $C$ with respect to $d$ on $\Delta \lambda$. In this way it was possible (1) to identify the life-history traits that were most responsible for the difference between the $\lambda$-values of the 2 populations and (2) to compare the contribution of each trait to the $\Delta \lambda$ between the 2 populations.

We also calculated the life expectancy:

$$
e^{0}=0.5+\frac{l_{1}+l_{2}+l_{3}+\ldots l_{n}}{l_{0}}
$$


the net reproductive rate:

$$
R_{0}=\sum_{i} F_{i} \prod_{j=1}^{i-1} P_{j}
$$

and the generation time:

$$
T=\frac{\sum_{i} i F_{i} \prod_{j=1}^{i-1} P_{j}}{\sum_{i} F_{i} \prod_{j=1}^{i-1} P_{j}}
$$

Statistical analysis of the demographic data was performed by resampling methods. The $95 \%$ CIs of the parameters under consideration were estimated by the percentile method, based on 2000 bootstrap-generated estimates (Levin et al. 1996, Caswell 2000). Permutation tests were used to highlight significant differences in the demographic parameters of the population considered (Levin et al. 1996).

\section{RESULTS}

\section{Life cycle}

In all the populations studied, the sex ratio was $1: 1$, both parents shared parental care for the developing embryos, the larvae hatched with 2 to 3 setigerous segments and the age at hatching was very similar ( 7 to $8 \mathrm{~d}$ ) (Table 1 ).

The other life-history characteristics differed. The individuals from Leghorn matured after only $34.9 \mathrm{~d}$, those from Taranto after $44.2 \mathrm{~d}$ and those from Ravenna after $50.8 \mathrm{~d}$ (Table 1). The mean life spans also differed: individuals from Leghorn survived from a minimum of 68 to a maximum of $297 \mathrm{~d}$, with a mean of $217 \mathrm{~d}$; those from Taranto survived from 88 to $279 \mathrm{~d}$ with a mean of $196 \mathrm{~d}$; those from Ravenna survived from 133 to $223 \mathrm{~d}$ with a mean of $174 \mathrm{~d}$ (Table 1).

Size of females at maturity, mean size of adult females and also mean size of adult males were different (Table 1). In the Leghorn population there was a marked sexual dimorphism, females being much big- ger than males (ANOVA: df $=61, F=108, p<0.001$ ). This dimorphism was also present in the Taranto group, albeit to a lesser degree (ANOVA: $\mathrm{df}=61, F=$ $140, \mathrm{p}<0.001)$, while in the Ravenna population the 2 sexes were the same size (ANOVA: $\mathrm{df}=67, F=2.46$, $\mathrm{p}=0.122$ ).

\section{Reproduction}

Reproductive characteristics of Ophryotrocha japonica varied among populations. The differences regarded the number of broods, time between broods, the number of eggs in each brood, size of the eggs, fecundity and the reproductive investment.

Females from Leghorn and Taranto in their life span laid, on average, 8.8 and 8.6 egg tubes, respectively, while Ravenna females only laid 5.7 (Table 2). There were also very marked differences in the number of reproductive events within each population; Leghorn females spawn from 2 to 15 times, Taranto females from 2 to 17 times and Ravenna females from 3 to 13 times.

Frequency of spawning differed among the 3 populations. Females from Leghorn spawned about every 19 d, while females from Taranto and Ravenna spawned at intervals of ca. $15 \mathrm{~d}$ (Table 2).

The number of eggs laid at each varied greatly in the 3 populations. The most fecund was the Leghorn population, the tubes containing on average 205 eggs, with a minimum of 12 and a maximum of 560. Taranto females spawned fewer eggs, each egg tube containing on average 85 eggs, with a minimum of 15 and a maximum of 192. Ravenna females generally laid more eggs at each reproductive event, each egg tube containing on average 135 eggs, with a minimum of 16 and a maximum of 310 (Table 2).

The size of eggs was also different among populations. Females from Leghorn laid eggs measuring $147 \mu \mathrm{m}$, while females from Ravenna and Taranto produced eggs with a mean diameter of 158 and $159 \mu \mathrm{m}$, respectively (Table 2).

Table 1. Ophryotrocha japonica. Life-cycle traits of the 3 populations studied (mean $\pm 2 \mathrm{SE}$ ), with ANOVA and LSD test of the

\begin{tabular}{|c|c|c|c|c|c|}
\hline & \multicolumn{3}{|c|}{ Population } & \multirow{2}{*}{$\begin{array}{l}\text { Statistics } \\
\text { ANOVA }\end{array}$} & \multirow[b]{2}{*}{ LSD } \\
\hline & Leghorn (L) & Taranto (T) & Ravenna (R) & & \\
\hline Age at hatching $(\mathrm{d})$ & $7.50 \pm 1.12$ & $8.17 \pm 1.4$ & $7.83 \pm 0.96$ & $\mathrm{df}=91 ; F=0.74 ; \mathrm{p}=0.480$ & - \\
\hline Age at maturity (d) & $34.94 \pm 1.26$ & $44.17 \pm 1.92$ & $50.76 \pm 0.98$ & $\mathrm{df}=94 ; F=131 ; \mathrm{p}<0.001$ & L T R \\
\hline Life span (d) & $217 \pm 22$ & $196 \pm 18$ & $173 \pm 10$ & $\mathrm{df}=94 ; F=6.5 ; \mathrm{p}=0.002$ & $\mathrm{~L} \underline{\mathrm{TR}}$ \\
\hline Sex ratio ( $\%$ of males) & $49.0 \pm 2.4$ & $48.6 \pm 2.5$ & $49.8 \pm 2.2$ & $\mathrm{df}=91 ; F=0.254 ; \mathrm{p}=0.776$ & - \\
\hline Size of female at maturity (ss) & $17.1 \pm 0.4$ & $17.4 \pm 0.4$ & $18.6 \pm 0.4$ & $\mathrm{df}=94 ; F=21.0 ; \mathrm{p}<0.001$ & $\underline{\mathrm{LT}} \mathrm{R}$ \\
\hline Size of adult female (ss) & $27.2 \pm 1.2$ & $22.6 \pm 0.6$ & $22.4 \pm 0.6$ & $\mathrm{df}=94 ; F=38.5 ; \mathrm{p}<0.001$ & $\mathrm{~L} \mathrm{TR}$ \\
\hline Size of adult male (ss) & $19.7 \pm 0.6$ & $18.2 \pm 0.4$ & $21.7 \pm 0.4$ & $\mathrm{df}=94 ; F=46.0 ; \mathrm{p}<0.001$ & L T R \\
\hline
\end{tabular}
differences among populations. $\mathrm{ss}=$ number of setigerous segments. Age at maturity and life-span refer to females 
Table 2. Ophryotrocha japonica. Reproductive characteristics of the 3 populations studied (mean \pm 2 SE), with ANOVA and LSD tests of the differences among populations. Size of egg was derived from the mean between the longer and the shorter axes

\begin{tabular}{|c|c|c|c|c|c|}
\hline & \multicolumn{3}{|c|}{ Population } & \multirow{2}{*}{$\begin{array}{l}\text { Statistics } \\
\text { ANOVA }\end{array}$} & \multirow[b]{2}{*}{ LSD } \\
\hline & Leghorn (L) & Taranto $(\mathrm{T})$ & Ravenna (R) & & \\
\hline Age at hatching (d) & $7.50 \pm 1.12$ & $8.17 \pm 1.4$ & $7.83 \pm 0.96$ & $\mathrm{df}=91 ; F=0.74 ; \mathrm{p}=0.480$ & - \\
\hline Spawnings (tubes) & $8.8 \pm 1.4$ & $8.6 \pm 1.2$ & $5.7 \pm 0.6$ & $\mathrm{df}=94 ; F=11.1 ; \mathrm{p}<0.001$ & $\underline{L} \mathrm{~T} R$ \\
\hline Frequency of spawning (d) & $18.8 \pm 1.0$ & $15.2 \pm 0.8$ & $15.2 \pm 1.2$ & $\mathrm{df}=94 ; F=18.4 ; \mathrm{p}<0.001$ & $\mathrm{LTR}$ \\
\hline Number of eggs per brood & $205 \pm 14$ & $85 \pm 0.4$ & $135 \pm 8$ & $\mathrm{df}=94 ; F=152 ; \mathrm{p}<0.001$ & L T R \\
\hline Size of eggs $(\mu \mathrm{m})$ & $147 \pm 2$ & $159 \pm 2$ & $158 \pm 4$ & $\mathrm{df}=99 ; F=28.5 ; \mathrm{p}<0.001$ & $\mathrm{~L} \underline{\mathrm{TR}}$ \\
\hline Fecundity (eggs per female) & $1796 \pm 314$ & $755 \pm 138$ & $772 \pm 148$ & $\mathrm{df}=94 ; F=30.7 ; \mathrm{p}<0.001$ & $\mathrm{~L} \underline{\mathrm{TR}}$ \\
\hline $\begin{array}{l}\text { Reproductive investment } \\
\left(\mathrm{mm}^{3} \text { eggs per female) }\right.\end{array}$ & 5.68 & 3.02 & 3.07 & & \\
\hline
\end{tabular}

Table 3. Ophryotrocha japonica. Demographic parameters of the 3 populations studied (with upper and lower 95\% bootstrap CIs), and results of permutation test of differences among populations

\begin{tabular}{|c|c|c|c|c|c|}
\hline & \multicolumn{3}{|c|}{ - Population } & \multicolumn{2}{|c|}{ Permutation test } \\
\hline & Leghorn (L) & Taranto $(\mathrm{T})$ & Ravenna (R) & General & On pairs \\
\hline Life expectancy $e^{0}(\mathrm{wk})$ & $\begin{array}{c}24.6 \\
(19.9-28.9)\end{array}$ & $\begin{array}{c}26.3 \\
(22.7-29.2)\end{array}$ & $\begin{array}{c}23.4 \\
(21.1-25.4)\end{array}$ & $\mathrm{p}=0.146$ & - \\
\hline Net reproductive rate $R_{0}$ (female descendants per female) & $\begin{array}{c}706 \\
(544-874)\end{array}$ & $\begin{array}{c}349 \\
(281-421)\end{array}$ & $\begin{array}{c}361 \\
(300-432)\end{array}$ & $\mathrm{p}<0.001$ & $\mathrm{~L} \underline{\mathrm{TR}}$ \\
\hline Generation time $T$ (wk) & $\begin{array}{c}16.1 \\
(15.1-17.1)\end{array}$ & $\begin{array}{c}15.4 \\
(14.1-16.9)\end{array}$ & $\begin{array}{c}12.6 \\
(115-13.8)\end{array}$ & $\mathrm{p}<0.001$ & $\underline{\mathrm{LT}} \mathrm{R}$ \\
\hline Population growth rate $\lambda\left(\mathrm{wk}^{-1}\right)$ & $\begin{array}{c}2.26 \\
(2.17-2.35)\end{array}$ & $\begin{array}{c}1.83 \\
(1.79-1.87)\end{array}$ & $\begin{array}{c}182 \\
(1.79-1.85)\end{array}$ & $\mathrm{p}<0.001$ & $\mathrm{~L} \underline{\mathrm{TR}}$ \\
\hline
\end{tabular}

The females from Leghorn exhibited a mean overall fecundity greater than that of the females from Taranto and Ravenna, whose fecundity levels were very similar. A female from Leghorn laid on average 1796 eggs, while those from Taranto and Ravenna laid an average of 755 and 772 eggs, respectively (Table 2).

In all 3 populations the reproductive investment was very high, albeit very different. The Leghorn population produced $5.6 \mathrm{~mm}^{3}$ of eggs, which was almost twice that produced by the populations from Taranto and Ravenna (Table 2).

\section{Demography}

The age-specific survival curves of the 3 populations are shown in Fig. 1a. In the Leghorn population, the percentage of hatching was ca. $80 \%$, while in those from Ravenna and Taranto it was $94 \%$. In the Leghorn population, survival was greater than $60 \%$ until the Week 27, when it began to decline very slowly. The survival curves of the populations from Taranto and Ravenna were very similar until the Week 24; thereafter, survival of the Ravenna population decreased much more rapidly than that of the Taranto population. The maximum life span was $39 \mathrm{wk}$ in the population
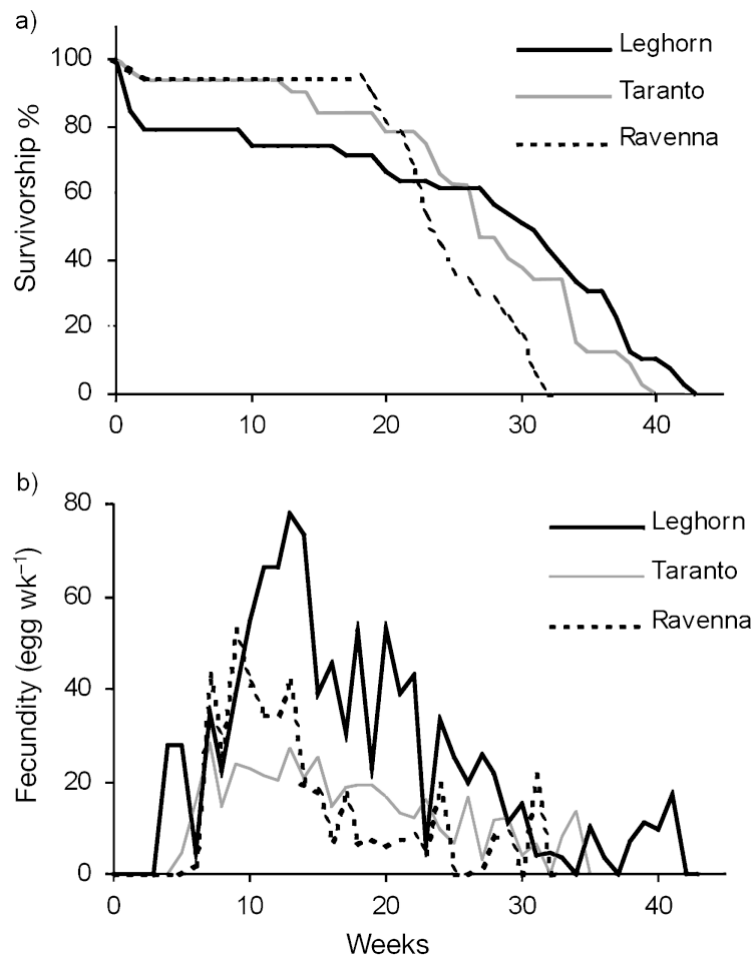

Fig. 1. Ophryotrocha japonica. (a) Survival- and (b) fecunditycurves of females in the 3 populations studied 

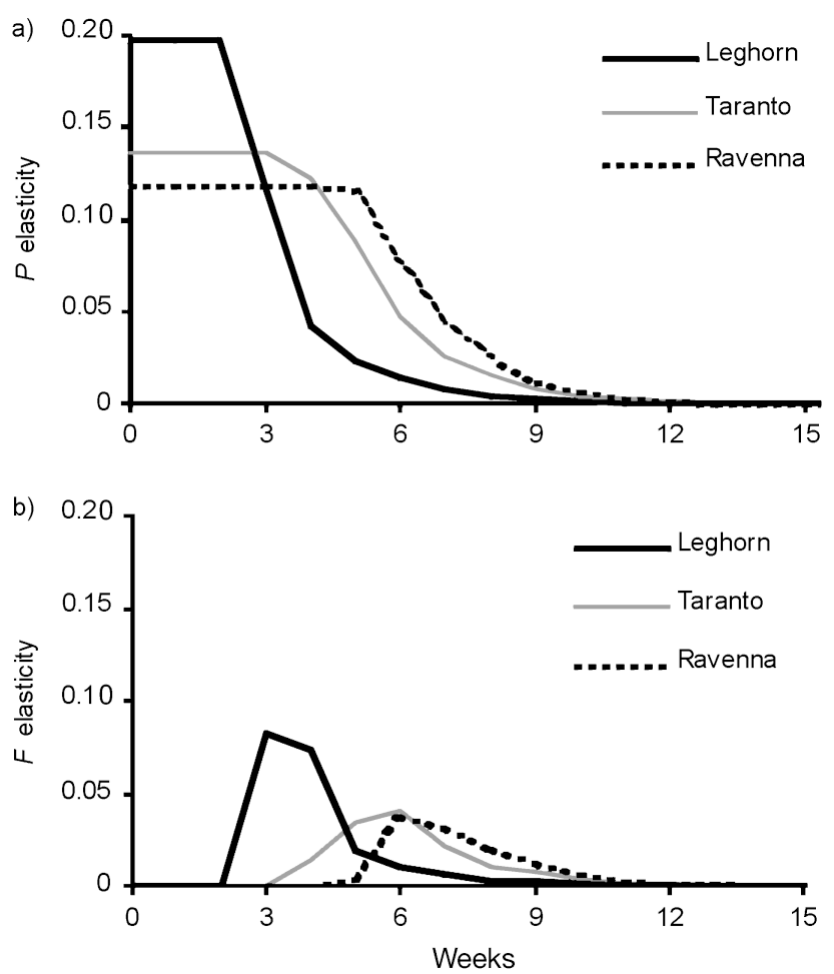

Fig. 2. Ophryotrocha japonica. Elasticity of (a) age-specific survival and (b) fecundity in the 3 populations studied

from Taranto and $31 \mathrm{wk}$ in that from Ravenna. The age-specific fecundity pattern is presented in Fig. 1b. Daily average fecundity showed different patterns in the 3 populations. The Leghorn population started laying in the 4th $\mathrm{wk}$, the Taranto population in the 5th wk and the Ravenna population in the 6th wk. The Leghorn population was also the most fecund; starting from the 4 th $w k$, its fecundity increased to reach a maximum of 78 eggs female ${ }^{-1} \mathrm{wk}^{-1}$ in the 13 th wk, after which it began to decline very gradually and in an irregular manner. The reproductive period of the Leghorn females was very long, many of them continuing to spawn until they died. In the Ravenna population, fecundity peaked in the 9 th wk (53 eggs female ${ }^{-1}$ $\mathrm{wk}^{-1}$ ) and the reproductive period ended around the Week 26. The Taranto population was the least fecund, maximum fecundity was 28 eggs $^{-1}$ female $^{-1} \mathrm{wk}$, corresponding to the 7 th wk of life. The females stopped reproducing after $34 \mathrm{wk}$.

Life expectancy at birth $\left(e^{0}\right)$, generation time $(T)$, net reproductive rate $\left(R_{0}\right)$ and the population growth rate $(\lambda)$ of the 3 strains of Ophryotrocha japonica are reported in Table 3. $e^{0}$ was similar in all populations (permutation test: $\mathrm{p}=0.146$ ). The longest life expectancy $(26.3 \mathrm{wk})$ was calculated for the Taranto population, the shortest (23.4 wk) for the Ravenna population. $R_{0}$ was significantly different in the 3 pop- ulations. The $R_{0}$-value was highest in the Leghorn strain $\left(R_{0}=706\right)$, the Ravenna and Taranto populations scoring 349 and 361, respectively. Also, $T$ was different in the 3 populations: in the Ravenna strain, the generation time ( $T=12.6 \mathrm{wk})$ was shorter than those recorded for the Taranto ( $T=15.4 \mathrm{wk}$ ) and the Leghorn strains $(T=16.1 \mathrm{wk})$. Population growth rate $\lambda$ was significantly different in the 3 groups. The $\lambda$-value calculated for the Leghorn population $\left(\lambda=2.26 \mathrm{wk}^{-1}\right)$ was higher than those obtained for Ravenna $(\lambda=$ $\left.1.82 \mathrm{wk}^{-1}\right)$ and Taranto $\left(\lambda=1.83 \mathrm{wk}^{-1}\right)$.

The elasticity patterns of $\lambda$ in response to variations in survival and age-specific fecundity in the 3 populations are shown in Fig. 2. In all groups, the elasticity of $\lambda$ in response to variations in survival was greater than that in response to variations in fecundity. Elasticity curves were shifted more towards the juvenile ageclasses in the Leghorn population than in the other 2, because the former reached maturity sooner and had a higher growth rate. In all cases, the period in which the population growth rate was influenced by the variations in survival and fecundity was limited to the first 9 to $12 \mathrm{wk}$ of life.

Decomposition analysis of the differences in $\lambda$ showed that the contributions of the different lifehistory traits, in terms of survival and age-specific fecundity, to the differences in fitness varied among the 3 populations (Fig. 3). The Leghorn-strain population growth rate was higher than the other 2 . This difference depended, above all, on the early attainment of sexual maturity and, to a lesser extent, on its greater fecundity. In particular, the contributions of enhanced fecundity during the first reproductive events were only partially limited by juvenile survival that, in the Leghorn population, was lower than in the other 2 (Fig. 3a,b). On the other hand, there were no significant differences between the growth rates of the Taranto and Ravenna populations. Decomposition analysis showed that the reproductive advantage of the Taranto population in the 5th and 6th wk of life was counterbalanced by the greater fecundity of the Ravenna population in the subsequent period (Fig. 3c).

\section{DISCUSSION}

The main life-history traits in the studied populations of Ophryotrocha japonica differed. There were morphological differences concerning a sort of sexual dimorphism based on body size in both the Leghorn and Taranto populations, but not in that from Ravenna. The most important differences, however, concerned the reproductive characteristics. Indeed, fecundity, defined both as the total number of eggs laid on average by each female and the number of reproductive 
events, varied greatly among populations: the Leghorn strain, which was the longest lived, recorded the highest number of broods, even though the intervals between successive broods were, on average, the longest.

The diameter of the eggs also varied, the eggs in the Leghorn population being smaller than those in the other 2. Since egg size for a given species is believed to be relatively constant and egg quality is correlated to egg size, egg size is probably the most frequently reported life-history character for marine invertebrates (Begon 1985, Levin et al. 1991, Qian \& Chia 1991, Stearns 1992). However, it has been observed that egg size can vary in response to variations in environmental parameters in the case of copepods (Brambilla 1982), echinoderms (Turner \& Lawrence 1979, Thompson 1982) and polychaetes (Qian \& Chia 1991, Prevedelli \& Zunarelli Vandini 1998). Differences in egg size under comparable environmental conditions have been observed in populations of Dinophilus gyrociliatus, an opportunistic polychaete which, like almost all the species of the genus Ophryotrocha, colonises harbour environments (Simonini \& Prevedelli 2003a,b). In $O$. japonica, there was a correlation between the number of eggs produced and their size: the Leghorn population, which is the most fecund, produces smaller eggs than the other 2. The Taranto and Ravenna populations, which produce eggs of the same size, had comparable fecundity. There was a trade-off between the number and the size of the oocytes (Begon 1985, Stearns 1992), which was highlighted by the comparison among populations. Also, some experimental studies on organisms belonging to various taxa such as bivalves, polychaetes and frogs have demonstrated correlations between egg size and the survival or growth rate of the offspring (Kraeuter et al. 1982, Levin et al. 1987, Williamson \& Bull 1989). In the case of O. japonica, there would appear to be a correlation between egg size and the number of larvae hatching; indeed, the Leghorn population, which produces the smallest eggs, had a lower hatching rate.

Morphometric and reproductive characteristics set the Leghorn population differed from the other 2 ; it reached sexual maturity more rapidly, lived longer and was decidedly larger. All these characteristics contributed to determine its greater fecundity. The great fecundity of the Leghorn population was not correlated only with reduced egg size; the reproductive investment of this strain was in fact almost twice that of the other 2 strains. The Taranto and Ravenna populations appeared to be more alike; their eggs were the same size, they were equally fecund and they made a similar reproductive investment. The differences between these 2 strains essentially concerned the number of eggs laid at each reproductive event. The Ravenna population reproduced less often but produced a larger number of eggs at each spawning, whereas the Taranto population laid a smaller number of eggs but in more frequent reproductive episodes. In these 2 populations there appeared to be a trade-off between present and future reproductive events (Hirshfield \& Tinkle 1975, Stearns 1992).

In many species of marine invertebrates, and of polychaetes in particular, differences have been observed in fecundity, not only of the individual, but also of the
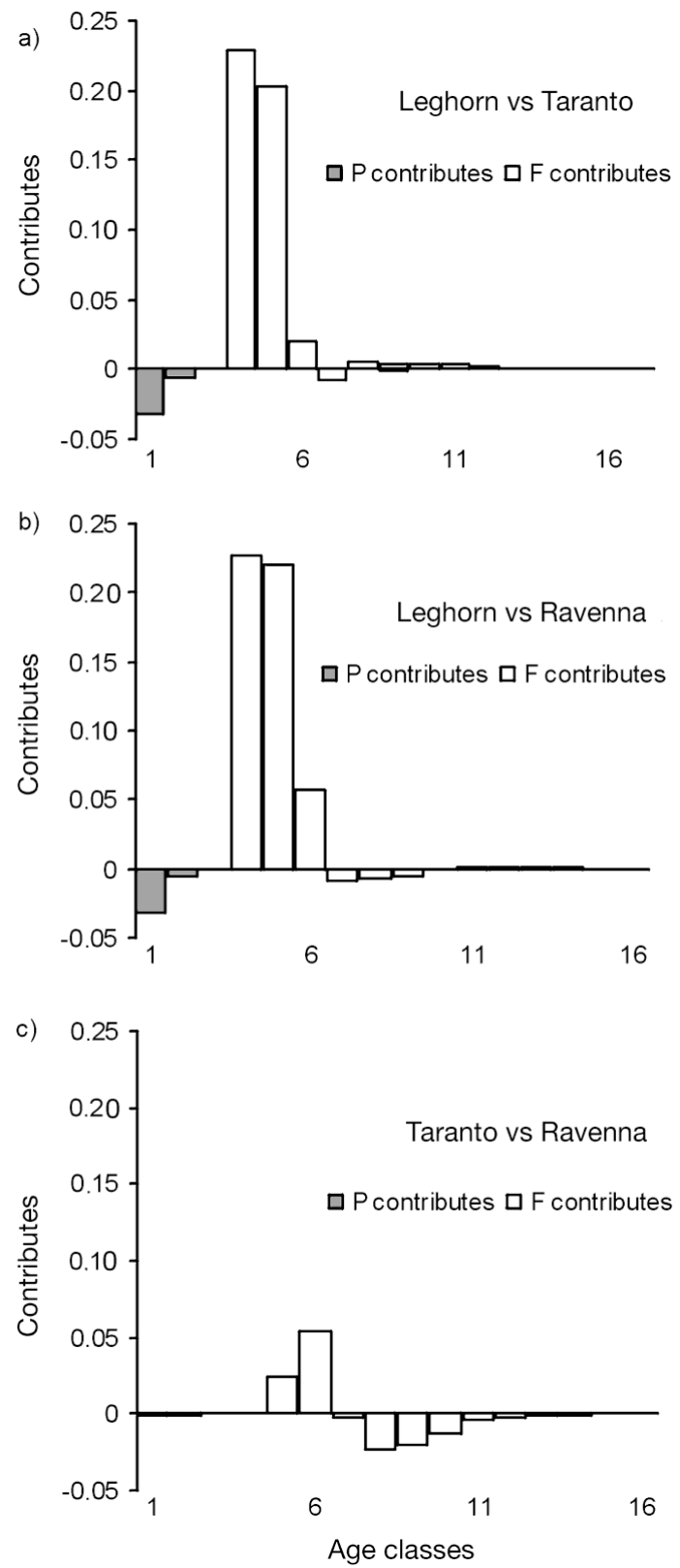

Fig. 3. Ophryotrocha japonica. Decomposition analysis of the differences in population growth rate, $\Delta \lambda$, of the 3 populations studied 
population as a whole, and these differences have been ascribed to differences in environmental parameters, particularly temperature and diet (Qian \& Chia 1991, Qian 1994, Prevedelli \& Zunarelli Vandini 1998, 1999, Simonini \& Prevedelli 2003a,b). In the present study, however, all 3 populations were kept under the same experimental conditions, and so the differences observed cannot be attributed to environmental factors. Differences in reproduction have been described in populations of the congeneric species, Ophryotrocha labronica, which Bacci (1978) has defined as sexual races. In geographically separate populations of this species, reproductive isolation on an ethological basis is also observed (Lanfranco \& Rolando 1981).

Differences in life-history characteristics had very important consequences for the demography and fitness of the populations. In the 3 strains of Ophryotrocha japonica, net growth rate $R_{0}$ and population growth rate $\lambda$, which are the indices of fitness most commonly used in evolutionary ecology, were in agreement: the highest $R_{0}$ - and $\lambda$-values were observed for the Leghorn population. The values of $R_{0}$, like those of $\lambda$, are also very similar in the Taranto and Ravenna populations.

The $\lambda$-values obtained for Ophryotrocha japonica are very similar to those calculated for $O$. diadema (Åkesson 1982) and O. labronica (Prevedelli \& Simonini 2001b), but decidedly higher than those of all the other opportunistic polychaetes characterised by a short lifespan, high fecundity and semi-continuous reproduction (Grassle \& Grassle 1974, Prevedelli \& Simonini 2002). Decomposition analysis shows that the differences in $\lambda$ among populations were due not to differences in survival, which was very similar in all populations during the first $10 \mathrm{wk}$ of life, but mainly to differences in fecundity. The demographic advantage of the Leghorn population depended on its greater fecundity during the early weeks of life. Shortening of the age at maturity afforded a far greater advantage than high fecundity, in accordance with all the studies on demography of opportunistic polychaetes (Lewontin 1965, Levin et al. 1986, 1996, Prevedelli \& Simonini 2002). Comparison between the Taranto and Ravenna populations, which had very similar $\lambda$-values, showed that the reproductive advantage gained by the Taranto strain in the early weeks of life was counterbalanced by the greater fecundity of the Ravenna population thereafter.

We do not believe it possible that Ophryotrocha japonica is a cosmopolitan species that has evaded previous surveys, for all species of Ophryotrocha found along the Italian coasts have been the object of intensive research, at both the morphological and reproductive level, since the 1960s (La Greca \& Bacci 1962, Robotti 1979, Lanfranco \& Rolando 1981, Rolando 1982,
Premoli \& Sella 1995, Prevedelli \& Zunarelli Vandini 1998). The wide distribution of O. japonica in lagoons and harbours, together with some characteristics of its life cycle, suggest that this species has been recently introduced either through maritime traffic or following the importation of species used in aquaculture. Comparison of the 3 populations of $O$. japonica highlights major differences in their biological cycle, life history and demography. The extreme selectivity of the harbour and lagoon environments may have led to fragmentation of the species into differentiated populations adapted to prevailing conditions in the different localities. This process might be supported by the considerable geographical distance among the populations studied and by the scant dispersal ability of O. japonica. Jürss et al. (1999) ascribed the differences between populations or siblings of the alien species Marenzelleria sp. to different colonising events. The marked differences observed among the 3 populations of $O$. japonica may therefore depend on the species' adaptation to different environmental situations, but could also be the result of independent introductions from different localities or at different times.

Acknowledgements. The authors wish to thank A. M. Bonvicini Pagliai and 3 anonymous reviewers for suggestions that greatly improved the manuscript. This work was supported by the Ministero dell'Istruzione, dell'Università e della Ricerca, Italy.

\section{LITERATURE CITED}

Åkesson B (1976) Temperature and life cycle in Ophryotrocha labronica (Polychaeta, Dorvilleidae). Ophelia 15:37-47

Åkesson B (1982) A life table study on three genetic strains of Ophryotrocha diadema (Polychaeta, Dorvilleidae). Int J Invertebr Reprod 5:59-69

Begon M (1985) A general theory of life-history variation. In: Sibly RM, Smith RH (eds) Behavioural ecology. Blackwell Scientific Publications, Oxford, p 91-97

Bacci G (1978) Genetics of sex determination in Ophryotrocha labronica (Annelida, Polychaeta). In: Battaglia B, Beardmore J (eds) Marine organisms. Plenum Press, New York, p 549-571

Brambilla DJ (1982) Seasonal variation of eggs size and number in a Daphnia pulex population. Hydrobiologia 97: $233-248$

Brommer JE (2000) The evolution of fitness in life-history theory. Biol Rev 75:377-404

Caswell H (2000) Matrix population models. 2nd edn. Sinauer, Sunderland, MA

Cognetti G (1982) Adaptive strategies of brackish-water fauna in pure and polluted water. Mar Poll Bull 13:247-250

Cognetti G (1994) Colonization of brackish waters. Mar Poll Bull 28:583-586

Giangrande A (1997) Polychaete reproductive patterns, life cycles and life histories: an overview. Oceanogr Mar Biol Annu Rev 35:323-386

Grassle JF, Grassle JP (1974) Opportunistic life history and genetic systems in marine benthic polychaetes. J Mar Res 32:253-284 
Grassle JF, Grassle JP (1976) Sibling species in the marine pollution indicator Capitella (Polychaeta). Science 192: $567-569$

Hansen FT, Forbes EV, Forbes TL (1999) Effects of 4-n-nonylphenol on life-history traits and population dynamics of a polychaete. Ecol Appl 9:482-495

Hirshfield MF, Tinkle DW (1975) Natural selection and the evolution of reproductive effort. Proc Natl Acad Sci USA 72:2227-2231

Huey RB, Barrigan D (2001) Temperature, demography, and ectotherm fitness. Am Nat 158:204-210

Jha AN, Hutchinson TH, Mackay JM, Elliot BM, Pascoe PL, Dixon DR (1995) The chromosomes of Platynereis dumerilii (Polychaeta: Nereidae). J Mar Biol Assoc UK 75:551-562

Jürss K, Röhner M, Bastrop R (1999) Enzyme activities and allozyme polymorphism in two genetic types (or sibling species) of the genus Marenzelleria (Polychaeta: Spionidae) in Europe. Mar Biol 135:489-496

Kraeuter JN, Castagna M, Dessel RV (1982) Egg size and larval survival of Mercenaria mercenaria (L.) and Argopecten irradians (Lamarck). J Exp Mar Biol Ecol 56:3-8

La Greca M, Bacci G (1962) Una nuova specie di Ophryotrocha delle coste tirreniche (Annelida, Polychaeta). Boll Zool 29:13-14

Lanfranco M, Rolando A (1981) Sexual races and reproductive isolation in Ophyotrocha labronica La Greca and Bacci (Annelida, Polychaeta). Boll Zool 48:291-294

Levin LA, Creed EL (1986) Effect of temperature and food availability on reproductive responses of Streblospio benedicti (Polychaeta: Spionidae) with planktotrophic or lecithotrophic development. Mar Biol 92:103-113

Levin LA, Caswell H, De Patra KD, Creed EL (1987) Demographic consequences of larval development mode: planktotrophy vs lecithotrophy in Streblospio benedicti. Ecology 68:1877-1886

Levin LA, Zhu J, Creed L (1991) The genetic basis of lifehistory characters in a polychaete exhibiting planktotrophy and lecithotrophy. Evolution 45:380-397

Levin LA, Caswell H, Bridges T, Di Bacco C, Plaia G (1996) Demographic responses of estuarine polychaetes to pollutants: life-table response experiments. Ecol Appl 6:1295-1313

Lewontin RC (1965) Selection for colonising ability. In: Baker HG, Stebbins GL (eds) The genetics of colonising species. Academic Press, New York, p 77-94

Mauri M, Simonini R, Baraldi E (2002) Demographic responses of the polychaete Dinophilus gyrociliatus to chromium exposure. Environ Toxicol Chem 21:1903-1907

Méndez N, Linke-Gamenick I, Forbes VE (2000) Variability in reproductive mode and larval development within the Capitella capitata species complex. Invertebr Reprod Dev 38:131-142

Pleijel F, Eide R (1996) The phylogeny of Ophryotrocha (Dorvilleidae: Eunicida: Polychaeta). J Nat Hist 30:647-659
Premoli MC, Sella G (1995) Sex economy in benthic polychaetes. Ethol Ecol Evolut 7:27-48

Prevedelli D, Simonini R (2001a) Effects of diet and laboratory rearing on demography of Dinophilus gyrociliatus (Polychaeta, Dinophilidae). Mar Biol 139:929-935

Prevedelli D, Simonini R (2001b) Effects of temperature on life history and demography of Ophryotrocha labronica (Polychaeta: Dorvilleidae). Vie Milieu 51:173-180

Prevedelli D, Simonini R (2002) Relationship between body size and population growth rate in two opportunistic polychaetes. J Mar Biol Assoc UK 82:403-408

Prevedelli D, Zunarelli Vandini R (1998) Effect of diet on reproductive characteristics of Ophryotrocha labronica (Polychaeta: Dorvilleidae). Mar Biol 132:163-170

Prevedelli D, Zunarelli Vandini R (1999) Survival, fecundity and sex ratio of Dinophilus gyrociliatus (Polychaeta: Dinophilidae) under different dietary conditions. Mar Biol 132: 163-170

Qian PY (1994) Effect of food quantity on growth and reproductive characteristics of Capitella sp. (Annelida: Polychaeta). Invertebr Reprod Dev 26:175-185

Qian PY, Chia FS (1991) Fecundity and egg size are mediated by food quality in the polychaete worm Capitella sp. J Exp Mar Biol Ecol 148:11-25

Robotti C (1979) Electrophoresis of proteins in three populations of Ophyotrocha labronica. Experientia 35:596-597

Rolando A (1982) Sexual condition in a population of Ophyotrocha robusta (Annelida, Polychaeta) from Genova. Atti Società toscana Scienze naturali (B) 89:145-152

Simonini R (2002) Distribution and ecology of the genus Ophryotrocha (Polychaeta: Dorvilleidae) in Italian harbors and lagoons. Vie Milieu 52:59-65

Simonini R, Prevedelli D (2003a) Effects of temperature on two Mediterranean populations of Dinophilus gyrociliatus (Polychaeta: Dinophilidae). I. Effects on life history and sex ratio. J Exp Mar Biol Ecol 291:79-93

Simonini R, Prevedelli D (2003b) Effects of temperature on two Mediterranean populations of Dinophilus gyrociliatus (Polychaeta: Dinophilidae). II. Effects on demographic parameters. J Exp Mar Biol Ecol 291:95-110

Stearns SC (1992) The evolution of life histories. Oxford University Press, New York

Thompson RJ (1982) The relationship between food ration and reproductive effort in the green sea urchin Strongylocentrotus droebachiensis. Oecologia 56:50-57

Turner RL, Lawrence J (1979) Volume and composition of echinoderm eggs: implications for the use of egg size in life-history models. In: Stancyk SC (ed) Reproductive ecology of marine invertebrates. University of South Carolina Press, Columbia, p 25-40

Williamson I, Bull CM (1989) Life history variation in a population of the Australian frog Ranidella signifera: egg size and early development. Copeia 1989:349-356 
Appendix 1. Ophryotrocha japonica. Life-table values and population-projection matrix elements of the 3 populations studied. $l_{x}$ : probability of surviving from birth to beginning of age class $x_{i} m_{x}$ : expected number of offspring for a female in age class $x_{i}$ $F_{i}$ : age-specific fecundity at age $i_{i} P_{i}$ : survival probabilities at age $i$

\begin{tabular}{|c|c|c|c|c|c|c|c|c|c|c|c|c|}
\hline \multirow{2}{*}{$\begin{array}{l}\text { Age (wk) } \\
x\end{array}$} & \multicolumn{4}{|c|}{ Leghorn } & \multicolumn{4}{|c|}{ — Taranto } & \multicolumn{4}{|c|}{ Ravenna } \\
\hline & $l_{X}$ & $m_{x}$ & $P_{i}$ & $F_{i}$ & $l_{X}$ & $m_{x}$ & $P_{i}$ & $F_{i}$ & $l_{x}$ & $m_{x}$ & $P_{i}$ & $F_{i}$ \\
\hline 0 & 1.000 & - & 0.889 & 0 & 1.000 & - & 0.968 & 0 & 1.000 & - & 0.972 & 0 \\
\hline 1 & 0.846 & 0 & 0.969 & 0 & 0.969 & 0 & 0.984 & 0 & 0.972 & 0 & 0.985 & 0 \\
\hline 2 & 0.795 & 0 & 1.000 & 0 & 0.937 & 0 & 1.000 & 0 & 0.944 & 0 & 1.000 & 0 \\
\hline 3 & 0.795 & 0 & 1.000 & 12.74 & 0.937 & 0 & 1.000 & 0 & 0.944 & 0 & 1.000 & 0 \\
\hline 4 & 0.795 & 27.71 & 1.000 & 25.64 & 0.937 & 0 & 1.000 & 2.20 & 0.944 & 0 & 1.000 & 0 \\
\hline 5 & 0.795 & 28.05 & 1.000 & 14.91 & 0.937 & 4.47 & 1.000 & 10.00 & 0.944 & 0 & 1.000 & 1.11 \\
\hline 6 & 0.795 & 4.37 & 1.000 & 18.10 & 0.937 & 15.85 & 1.000 & 21.74 & 0.944 & 2.25 & 1.000 & 22.40 \\
\hline 7 & 0.795 & 34.98 & 1.000 & 26.44 & 0.937 & 28.32 & 1.000 & 21.18 & 0.944 & 43.19 & 1.000 & 34.14 \\
\hline 8 & 0.795 & 22.50 & 0.968 & 27.80 & 0.937 & 14.72 & 1.000 & 18.86 & 0.944 & 26.06 & 1.000 & 38.85 \\
\hline 9 & 0.795 & 39.21 & 0.967 & 42.30 & 0.937 & 23.62 & 1.000 & 22.77 & 0.944 & 52.75 & 1.000 & 46.15 \\
\hline 10 & 0.745 & 54.59 & 1.000 & 55.51 & 0.937 & 22.65 & 1.000 & 21.67 & 0.944 & 40.85 & 1.000 & 37.20 \\
\hline 11 & 0.745 & 66.10 & 1.000 & 60.81 & 0.937 & 21.38 & 0.983 & 20.27 & 0.944 & 34.60 & 1.000 & 34.16 \\
\hline 12 & 0.744 & 66.12 & 1.000 & 66.16 & 0.937 & 20.13 & 0.983 & 23.17 & 0.944 & 34.68 & 1.000 & 37.61 \\
\hline 13 & 0.744 & 77.72 & 1.000 & 69.58 & 0.906 & 27.36 & 0.965 & 23.42 & 0.944 & 41.60 & 1.000 & 30.33 \\
\hline 14 & 0.744 & 73.55 & 1.000 & 51.71 & 0.906 & 20.95 & 0.964 & 22.36 & 0.944 & 19.93 & 1.000 & 18.55 \\
\hline 15 & 0.744 & 38.88 & 0.983 & 38.37 & 0.844 & 25.39 & 1.000 & 19.60 & 0.944 & 17.71 & 1.000 & 12.17 \\
\hline 16 & 0.744 & 45.33 & 0.982 & 34.48 & 0.844 & 14.44 & 1.000 & 16.32 & 0.944 & 6.97 & 1.000 & 11.98 \\
\hline 17 & 0.718 & 30.18 & 1.000 & 38.05 & 0.844 & 18.72 & 1.000 & 18.66 & 0.944 & 17.34 & 0.971 & 11.78 \\
\hline 18 & 0.718 & 52.55 & 0.964 & 34.26 & 0.844 & 19.19 & 0.963 & 18.62 & 0.944 & 6.76 & 0.924 & 6.81 \\
\hline 19 & 0.718 & 22.75 & 0.944 & 33.47 & 0.844 & 19.37 & 0.961 & 17.52 & 0.889 & 7.62 & 0.934 & 6.48 \\
\hline 20 & 0.667 & 52.96 & 0.980 & 41.91 & 0.781 & 16.88 & 1.000 & 14.67 & 0.806 & 5.90 & 0.912 & 6.26 \\
\hline 21 & 0.641 & 38.92 & 1.000 & 37.65 & 0.781 & 12.92 & 0.980 & 12.10 & 0.778 & 7.45 & 0.827 & 6.88 \\
\hline 22 & 0.641 & 42.94 & 0.980 & 22.47 & 0.781 & 11.90 & 0.918 & 13.14 & 0.667 & 7.87 & 0.814 & 5.68 \\
\hline 23 & 0.641 & 6.04 & 0.980 & 17.72 & 0.750 & 16.12 & 0.911 & 12.14 & 0.528 & 4.47 & 0.829 & 10.01 \\
\hline 24 & 0.615 & 33.17 & 1.000 & 26.82 & 0.656 & 9.38 & 0.976 & 7.80 & 0.444 & 19.09 & 0.862 & 9.41 \\
\hline 25 & 0.615 & 25.15 & 1.000 & 20.58 & 0.625 & 6.62 & 0.875 & 10.53 & 0.361 & 0 & 0.880 & 0 \\
\hline 26 & 0.615 & 19.60 & 0.958 & 20.43 & 0.625 & 16.87 & 0.857 & 9.57 & 0.333 & 0 & 0.909 & 0.67 \\
\hline 27 & 0.615 & 25.90 & 0.935 & 21.24 & 0.469 & 3.00 & 0.933 & 6.80 & 0.278 & 1.50 & 0.900 & 4.29 \\
\hline 28 & 0.564 & 21.70 & 0.953 & 14.76 & 0.469 & 11.60 & 0.893 & 10.98 & 0.278 & 8.00 & 0.778 & 7.20 \\
\hline 29 & 0.538 & 10.90 & 0.951 & 11.58 & 0.406 & 12.00 & 0.920 & 7.64 & 0.222 & 8.50 & 0.571 & 4.19 \\
\hline 30 & 0.513 & 15.00 & 0.923 & 8.66 & 0.375 & 3.83 & 0.956 & 4.99 & 0.167 & 0 & 0.250 & 2.62 \\
\hline 31 & 0.487 & 4.16 & 0.889 & 3.78 & 0.344 & 6.59 & 1.000 & 3.24 & 0.056 & 21.25 & 0 & 10.48 \\
\hline 32 & 0.436 & 4.56 & 0.875 & 3.46 & 0.344 & 0.00 & 0.727 & 2.94 & 0 & 0 & & \\
\hline 33 & 0.385 & 3.40 & 0.893 & 1.56 & 0.344 & 8.23 & 0.562 & 7.90 & & & & \\
\hline 34 & 0.333 & 0.00 & 0.960 & 4.43 & 0.156 & 13.90 & 0.889 & 6.84 & & & & \\
\hline 35 & 0.308 & 10.04 & 0.875 & 6.11 & 0.125 & 0 & 1.000 & 0 & & & & \\
\hline 36 & 0.308 & 3.71 & 0.667 & 1.71 & 0.125 & 0 & 0.875 & 0 & & & & \\
\hline 37 & 0.231 & 0.00 & 0.643 & 8.52 & 0.125 & 0 & 0.571 & 0 & & & & \\
\hline 38 & 0.128 & 28.80 & 0.889 & 13.25 & 0.094 & 0 & 0.250 & 0 & & & & \\
\hline 39 & 0.103 & 45.25 & 0.875 & 20.81 & 0.031 & 0 & 0 & 0 & & & & \\
\hline 40 & 0.103 & 38.63 & 0.571 & 17.76 & 0 & 0 & & & & & & \\
\hline 41 & 0.077 & 68.50 & 0.250 & 31.51 & & & & & & & & \\
\hline 42 & 0.026 & 0 & 0 & 0 & & & & & & & & \\
\hline 43 & 0 & 0 & & & & & & & & & & \\
\hline
\end{tabular}

Editorial responsibility: Otto Kinne (Editor), Oldendorf/Luhe, Germany
Submitted: November 20, 2002; Accepted: June 24, 2003 Proofs received from author(s): August 12, 2003 